\title{
PGBL inhibits the RAW 264.7 cells to express inflammatory factor
}

\author{
Chunmei Zhang ${ }^{\mathrm{a}}$, Linghui Lin ${ }^{\mathrm{a}}$, Guirong Li ${ }^{\mathrm{b}}$, Jianan $\mathrm{Ma}^{\mathrm{a}}$, Xu Han ${ }^{\mathrm{a}}$ and Rui Fei ${ }^{\mathrm{a},{ }^{*}}$ \\ ${ }^{a}$ Department of Cell Biology, College of Basic Medical Sciences, Jilin University, Changchun, Jilin \\ 130021, P.R. China \\ ${ }^{\mathrm{b}}$ Department Of Ophthalmology, Second Hospital, Jilin University, Changchun 130041, P.R. China
}

\begin{abstract}
Polysaccharides derived from Ginkgo biloba leaf (PGBL) is a kind of active ingredient came out from ginkgo biloba leaf extractions. Previous studies have shown that PGBL has a good anti-inflammatory effect. However, the mechanism is not clear. This study is to investigate the modulated immunity effect of PGBL on RAW264.7 cells. Here we showed that lipopolysaccharide (LPS) induces the expression of tumor necrosis factor- $\alpha$ (TNF- $\alpha$ ) and interleukin-6 (IL-6), and this induction can be repressed by PGBL treatment both in protein level and mRNA level, and PGBL strongly reduced the translocation of nuclear factor (NF)- $\mathrm{BB}$ to the cell nucleus. These findings demonstrate that PGBL can decrease the sensitivity of monocytes to LPS, and PGBL has applications in systemic inflammation and immune diseases.
\end{abstract}

Keywords: LPS, PGBL, TNF- $\alpha$, IL-6, NF- $\kappa$ B

\section{Introduction}

Macrophages are major participants in innate immunity responses which recognize, phagocytose and eliminate [1]. Macrophages have a variety of complex functions in specific and non-specific inflammatory process, such as the monitoring of the target organisms, chemotaxis, phagocytosis and destroy [2]. In addition, macrophages as antigen-presenting cells and with the interaction of $\mathrm{T}$ lymphocytes to regulate the adaptive immune response, embryonic development, tissue remodeling, wound healing and clearance of apoptotic cells $[3,4]$. Lipopolysaccharide (LPS) activates immune cells to up-regulate inflammatory responses and causes the production of pro-inflammatory cytokines [5]. LPS-activated macrophage cells usually secrete a variety of inflammatory cytokines, such as tumor necrosis factor- $\alpha$ (TNF- $\alpha$ ), interleukin 6 (IL-6). However, excessive cytokines and inflammatory mediators may lead to a systemic inflammatory response syndrome (SIRS), even severe tissue damage and endotoxin shock [6]. According to the report, PGBL can significantly inhibit mouse NK cells, T cells, and lymphocyte activity. The activation and improving celiac phagocytes to chicken blood red cell to gobble up the index, shows that PGBL owns strong activation nonspecific immune regulating function [7].

Inflammation is a complex pathological reaction, and the internal mechanism is also very complex.

\footnotetext{
*Address for correspondence: Rui Fei, Department of Cell Biology, College of Basic Medical Sciences, Jilin University, Changchun, Jilin 130021, P.R. China, Tel.:+86 0431 85619473; Fax: +86 0431 85619105; E-mail: feirui@jlu.edu.cn.
}

0959-2989/15/\$35.00 @ 2015 - IOS Press and the authors. 
Our previous studies proved that PGBL could inhibit P-selectin mediated leukocyte adhesion and ooze inhibition in mice with acute abdominal inflammation [8]. However, it is unclear that whether PGBL has a direct role in the inflammatory cells or in the expression of inflammatory cytokines. Our study shows that PGBL play a role on the inflammatory cells RAW264.7, which may demonstrate the antiinflammatory mechanism and provides the experimental foundation for development and utilization of PGBL.

\section{Materials and methods}

\subsection{Materials and cell culture}

Cell lines RAW264.7 were purchased from the Cell Bank of the Chinese Academy of Sciences (Shanghai, China). MTT (AMRESCO). PGBL was extracted by our laboratory [9]. Anti-NF $\kappa B$ p65 Purified (eBioscience) LPS and Trizol were purchased from Sigma. RAW264.7 cells were cultured in RPMI 1640 (Gibco) supplemented with $10 \%$ fetal bovine serum (FBS) at $37^{\circ} \mathrm{C}$ in the presence of $5 \%$ $\mathrm{CO}_{2}$.

\subsection{Cytotoxicity of PGBL in RAW264.7 cells}

The 3-[4, 5-dimethylthiazol-2-yl]-2, 5-diphenyl tetrazolium bromide (MTT) assay was used to measure the cytotoxicity of PGBL. Cells were cultured in 96-well plates and then incubated with various concentrations of PGBL $(0,1.5,2.5,3.5,4.5 \mathrm{mg} / \mathrm{ml})$ for $24 \mathrm{~h}$. Subsequently, $5 \mathrm{mg} / \mathrm{ml}$ of MTT was added to each well and cultured for $4 \mathrm{~h}$ at $37^{\circ} \mathrm{C}$. Dimethyl sulfoxide was added and then recorded by DIAS Microplate Reader (TECAN).

\subsection{Cell viability analysis}

The MTT assay was used to measure the cell viability. Cells were incubated in 96-well plates for 24 $\mathrm{h}, 48 \mathrm{~h}$ or $72 \mathrm{~h}$ separately, adding nutrient solution as a blank control group, adding LPS $1 \mu \mathrm{g} / \mathrm{ml}$ as the model group and adding 1.5, 2.5, 3.5, $4.5 \mathrm{mg} / \mathrm{ml}$ of PGBL and $1 \mu \mathrm{g} / \mathrm{ml}$ of LPS as the drug control group. Subsequently, cells were treated with $5 \mathrm{mg} / \mathrm{ml}$ of MTT for $4 \mathrm{~h}$ at $37^{\circ} \mathrm{C}$. Dimethyl sulfoxide was added and then recorded by DIAS Microplate Reader (TECAN).

\subsection{Enzyme-linked immunosorbent assay}

To determine the amount of secreted IL- 6 and TNF- $\alpha$, cells were pretreated with various concentrations of PGBL for 24 or $48 \mathrm{~h}$ followed by LPS stimulation $(1 \mu \mathrm{g} / \mathrm{ml})$. After treatment, the supernatants were collected for further cytokine analysis. ELISA kits were used to determine the concentrations of TNF- $\alpha$ and IL-6.

\subsection{RNA isolation and semi-quantitative RT-PCR}

TRIzol reagent was used to extract the total RNA in cells. Subsequently, chloroform and propanol were used to separate the RNAs from DNAs and proteins. After washed, the dry RNAs were dissolved in propanol of RNA-free water. RT-PCR system was used to produce cDNA. It was run on $1 \%$ agarose gels and then stained after. A densitometric analysis was performed using Image $\mathrm{J}$ software. 


\subsection{Western blot}

RAW264.7 cells were pretreated with different concentrations of PGBL, and stimulated by $1 \mu \mathrm{g} / \mathrm{ml}$ LPS for $6 \mathrm{~h}$. PIKA extraction reagents (INVITROGEN) were used to extract proteins. Proteins were denatured and resolved by SDS-PAGE, and then transferred on the nitrocellulose membranes. After blocked with 5\% nonfat milk and washed, the NC membranes were indicated with the primary antibodies and the HRP conjugated secondary antibodies respectively. Chemiluminescent detection was performed by using ECL Plus western blotting reagents.

\subsection{Statistical analysis}

All experiments were repeated at least 3 times. Values are expressed as the mean \pm S.D. Statistical analysis was performed with analysis of ariance (ANOVA) and Student's $t$-test.

\section{Results}

\subsection{Effect of PGBL on viability of LPS-stimulated RAW 264.7 cells}

At first, the cytotoxicity of PGBL was assessed. As shown in Figure 1A, the viability of RAW264.7 cells could not be affected by different doses of PGBL $(1.5,2.5,3.5,4.5 \mathrm{mg} / \mathrm{ml})$. Hence these concentrations of PGBL were considered suitable for further assays.

We examined the viability of RAW264.7 cell stimulated by LPS. The data showed that it is slight time-related process, and $1 \mu \mathrm{g} / \mathrm{ml}$ of LPS is sufficient to build this experimental model of inflammatory cells. We next investigated the Effect of PGBL on viability of LPS- activated RAW 264.7 cells. As shown in Figure 1B, for $24 \mathrm{~h}$, different concentration of PGBL groups all can inhibit the viability of RAW264.7 inflammatory cells, but displayed somewhat concentration dependence. The group of $4.5 \mathrm{mg} / \mathrm{ml}$ PGBL compared to the model group (LPS group) displays a significant difference $(\mathrm{P}<0.05)$. The group of $3.5 \mathrm{mg} / \mathrm{ml}$ PGBL can effectively inhibit the viability of inflammatory cells RAW264.7 after $48 \mathrm{~h}$, and shows a clear contrast $(\mathrm{P}<0.05)$ with LPS group.

A

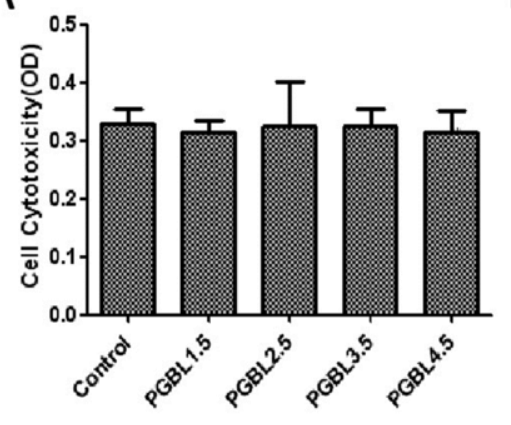

B

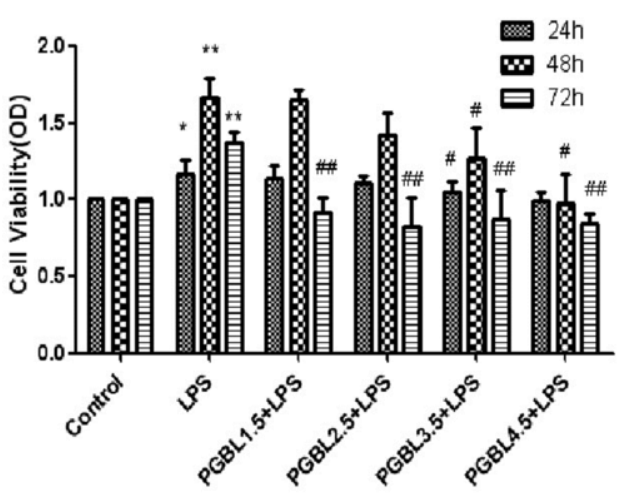

Fig. 1. PGBL hasn't impaired the viability of RAW264.7 cells. (A), Cells were treated with PGBL in a range of 1.5-4.5 $\mathrm{mg} / \mathrm{ml}$ for $24 \mathrm{~h}$. The cytotoxicity of PGBL was analyzed by the MTT assay. (B), RAW264.7 cells were incubated with PGBL and then activated with LPS. MTT assay was used to measure the cell viability. (compared to the control group $* \mathrm{P}<0.05$, $* * \mathrm{P}$ $<0.01$; Compared with the LPS-treated group \# \#p $<0.01$, \#p $<0.05$ ). 


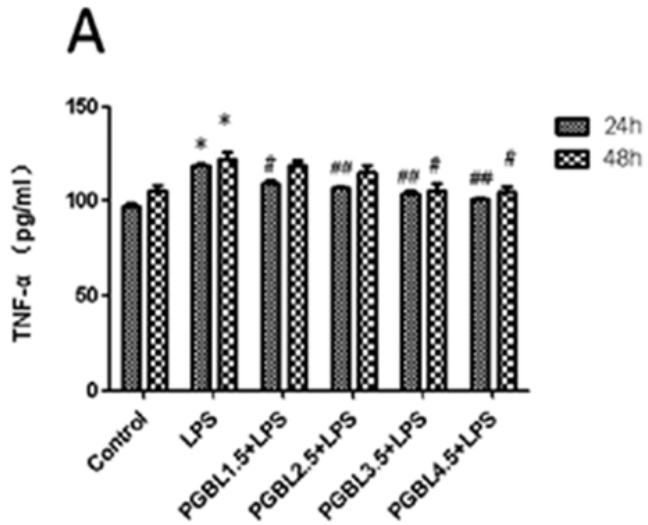

B

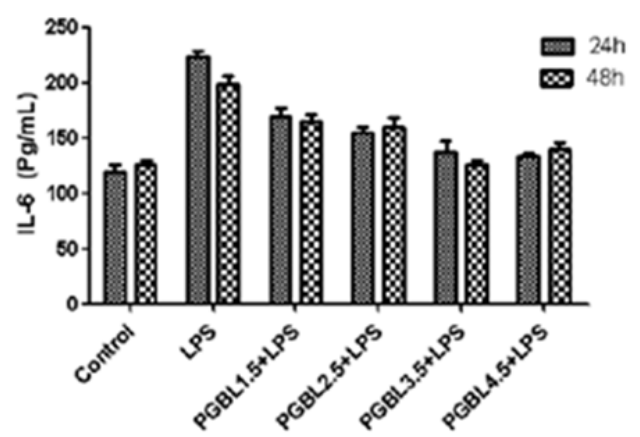

Fig. 2. PGBL inhibits the production of TNF- $\alpha$ and IL-6 in LPS-stimulated RAW 264.7 Cells. (A) and (B), Cells were incubated with or without LPS $(1 \mu \mathrm{g} / \mathrm{ml})$ for $24 \mathrm{~h}$ or $48 \mathrm{~h}$ in the presence or absence of PGBL $(1.5,2.5,3.5,4.5 \mathrm{mg} / \mathrm{ml})$. The concentrations of TNF- $\alpha$ and IL-6 in cell culture supernatants were determined by ELISA kits. Each column represents the mean $\mathrm{S} \pm \mathrm{D}$. from 3 times independent experiments (Compared with the blank control $* \mathrm{p}<0.05$; Compared with the LPS group \#\# $\mathrm{p}<0.01$, \# $\mathrm{p}<0.05)$.

Except the group of $1.5 \mathrm{mg} / \mathrm{ml}$ PGBL (P> 0.05 compared with LPS group), all the other PGBL groups show limited difference $(\mathrm{P}<0.01)$ after $72 \mathrm{~h}$, and the best concentration is $2.5 \mathrm{mg} / \mathrm{ml}$. In the same concentration prominent under different action time conditions, PGBL incubated for 72 hours have a most significant effect. these results show that PGBL have an obvious effect on the viability of inflammatory cells RAW264.7 cells, and the optimal concentration is $2.5 \mathrm{mg} / \mathrm{ml}$ and $72 \mathrm{~h}$ is enough long to observe the effect.

\subsection{PGBL inhibits the production of TNF- $\alpha$ and $I L-6$}

To determine whether PGBL decreases the activation of LPS-stimulated RAW264.7 cells, the production of TNF- $\alpha$ and IL-6 were examined by ELISA. As shown in Figure 2A, RAW264.7 cells were stimulated by LPS $(1 \mu \mathrm{g} / \mathrm{ml})$ for $24 \mathrm{~h}$, the model group (LPS group) medium supernatant of TNF- $\alpha$ contents increased obviously, and there is a significant difference $(\mathrm{p}<0.05)$ when compared with the control group. LPS and different concentrations of PGBL $(1.5,2.5,3.5,4.5 \mathrm{mg} / \mathrm{ml})$ coincubated for 24 h, RAW264.7 cells culture medium supernatant TNF- $\alpha$ were significantly reduced. Moreover, the inhibition is concentration-dependent. After $48 \mathrm{~h}$, groups with PGBL concentration more than $3.5 \mathrm{mg} / \mathrm{ml}$ has a significant inhibition on the secretion of TNF- $\alpha$, while the lower concentrations all have no effectively inhibitory affection $(\mathrm{P}>0.05)$. As show in Figure $2 \mathrm{~B}$, the differences between the PGBL treated and LPS group were significant at concentrations of 3.5, 4.5 $\mathrm{mg} / \mathrm{ml}$. This showed that PGBL inhibited the releasing TNF- $\alpha$ and IL- 6 by LPS-induced inflammatory cells RAW264.7. The inhibition rate increases along with the concentration, the inhibition effect decreases along with the extension time.

\subsection{PGBL suppresses $T N F-\alpha$ and IL-6 gene transcription}

We have further investigated the effect of PGBL on transcription level of TNF- $\alpha$ and IL- 6 . The results of LPS $(1 \mu \mathrm{g} / \mathrm{ml})$ stimulus RAW264.7 cells for $6 \mathrm{~h}$ was shown in Figure 3A. The model group (LPS group) of TNF- $\alpha$ mRNA was significantly elevated $(\mathrm{P}<0.05)$. When different concentrations 

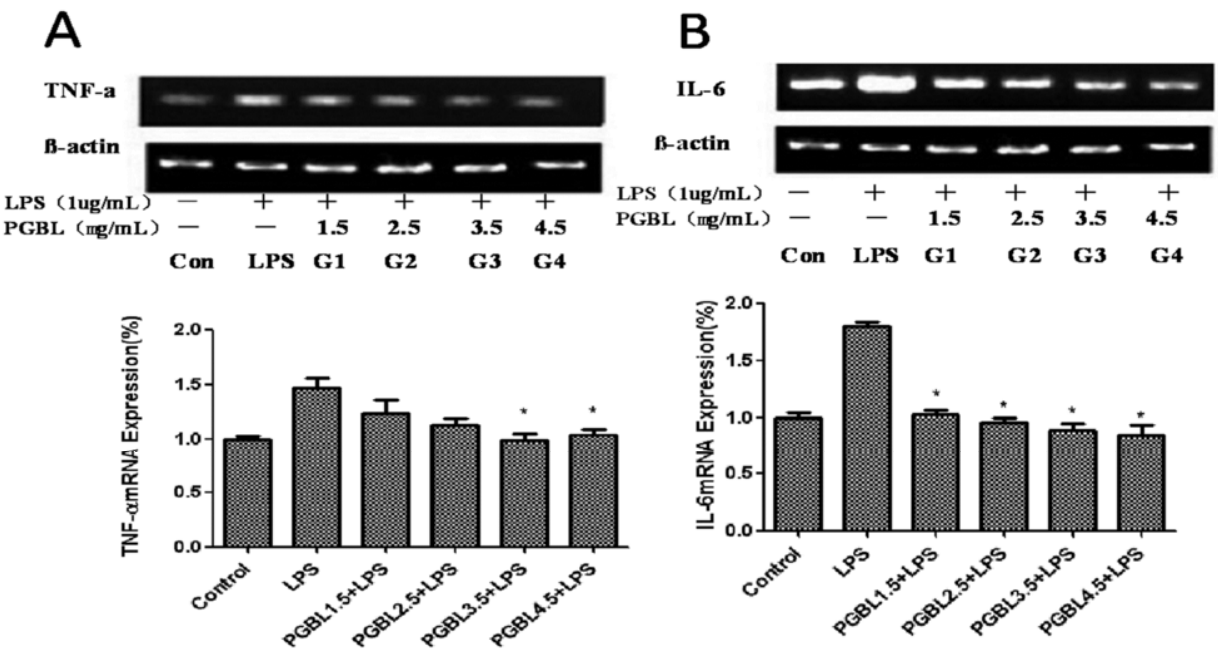

Fig. 3. PGBL suppresses the TNF- $\alpha$ and IL-6 mRNA level. Cells were stimulated for $6 \mathrm{~h}$ with LPS (1 $\mu \mathrm{g} / \mathrm{ml})$ or treated with various concentrations of PGBL $(0,1.5,2.5,3.5$ and $4.5 \mathrm{mg} / \mathrm{ml})$ and LPS $(1 \mu \mathrm{g} / \mathrm{ml})$. Semi-quantitative PCR were used to analysis the mRNA. Compared with the LPS group ${ }^{*} \mathrm{p}<0.05$.

PGBL were added to incubate for $6 \mathrm{~h}$, TNF- $\alpha$ mRNA was significantly suppressed. PGBL concentration is much higher than $3.5 \mathrm{mg} / \mathrm{ml}$, more obvious difference is displayed to LPS group $(\mathrm{P}<0.05)$. The results point out that PGBL can inhibit the transcription of TNF- $\alpha$ mRNA effectively. As shown in Figure 3B, LPS $(1 \mu \mathrm{g} / \mathrm{mL})$ stimulus RAW264.7 cells for $6 \mathrm{~h}$, Model group (LPS group) of IL-6 mRNA was significantly elevated. When different concentrations PGBL were added to incubate for $6 \mathrm{~h}$, IL-6 mRNA was significantly suppressed, and there is a significant difference $(\mathrm{P}<0.05)$. The results showed that PGBL also can restrain IL-6 mRNA transcription, and it presents an obviously dose dependence.

\section{4. $P G B L$ inhibited $N F-\kappa B$ expression}

As we known that LPS can trigger NF- $\mathrm{BB}$ activation and then augment the production of inflammatory cytokines [9]. To determine whether NF- $\mathrm{KB}$ is also involved in the protective effect of PGBL on inflammation, the production of NF- $\mathrm{KB}$ p65 in LPS-induced RAW264.7 cells was measured. As shown in Figure 4, LPS can significantly induce NF- $\kappa B$ expression in RAW264.7 cells. In contrast, PGBL $(1.5,2.5,3.5,4.5 \mathrm{mg} / \mathrm{ml})$ suppressed NF- $\kappa B$ protein level. Hence, it is suggested that PGBL suppresses the inflammatory response through the inhibition of NF- $\mathrm{B}$ expression in LPS-stimulated RAW264.7 cells.

\section{Discussion}

Lipopolysaccharide (LPS) is a typical inflammatory stimulus, which can trigger inflammation and activate the cellular signal transduction, and causes the intracellular cascades [10]. LPS activates macrophages and detects the characteristics of the cells, which is a common means to evaluate the anti-inflammatory activity of many drugs. Therefore, in this research we utilized LPS to induce macro phage RAW264.7 inflammatory response, and investigate its anti-inflammatory effect and determine 

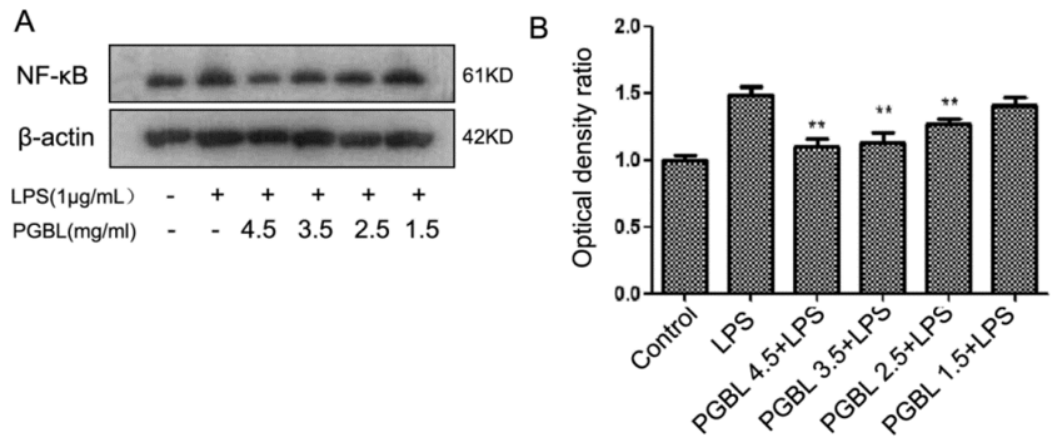

Fig. 4. PGBL suppresses NF-kB p65 production in activated RAW264.7 cells. Cells were lysed after $24 \mathrm{~h}$ treated with or without LPS and PGBL. Lysates were blotted with NF- $\mathrm{kB}$ p65 and actin antibodies. The data are from 3 independent experiments. Compared with the LPS group $* * \mathrm{p}<0.01$.

the mechanism of PGBL on the cellular level and molecular level. Our experiment results show that LPS can activate RAW264.7 cells effectively, and induce expression of inflammatory cytokines IL-6 and TNF- $\alpha$. Furthermore, it also can promote the gene transcription of IL- 6 and TNF- $\alpha$ mRNA. In addition, our experimental results also showed that the doses of PGBL $(1.5,2.5,3.5,4.5 \mathrm{mg} / \mathrm{ml})$ have no effect on the viability of RAW264.7 cells experimentally. These results further demonstrate a proinflammatory effect of LPS on macrophages, and provide a reliable inflammatory model as well as a proper concentration range of PGBL for the follow-up experiments.

Inflammation is a very complex process, including the accumulation of inflammatory cells, proliferation and production of inflammatory cytokines [11]. Macrophages function by releasing proinflammatory cytokines, such as TNF- $\alpha$, IL-6 [12]. These cytokines play a principal role in inflammatory diseases and processes [13]. Hence, it is an effective means to prevent the occurrence and development of inflammatory response by blocking the excessive production of inflammatory cytokines [14]. TNF- $\alpha$, which can cause pro-inflammatory effects to many types of cells, is produced by mononuclear cells, macrophages and T cells. IL-6 is regarded as an endogenous mediator of LPSinduced fever [15]. Our study found that, under certain conditions, PGBL can significantly reduce the mRNA and protein level of TNF- $\alpha$ and IL-6 in RAW264.7 cells. These results suggested that PGBL could play an anti-inflammatory role by inhibiting TNF- $\alpha$, and IL- 6 gene transcription and protein expression.

$\mathrm{NF}-\kappa \mathrm{B}$ family is a protein family and composed of complex polypeptide subunit. NF- $\mathrm{BB}$ plays a central role in a number of signal pathways in monocytes/macrophages as a transcriptional factor [16]. It also functions in triggering and coordinating, initiating and (triggering, coordinating, initiating and implementing) adaptive immune responses [17-19]. Some natural products are eligible candidates for potential NF- $\mathrm{KB}$ inactivators [20]. Our investigation found that LPS can increase the expression of

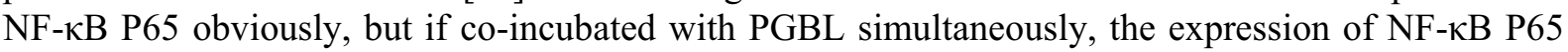
was significantly decreased and the decrease is dose-dependent. The data demonstrated that PGBL can suppress inflammatory response by inhibiting the production of NF- $\mathrm{BB}$ in LPS-stimulated RAW264.7 cells.

It well known that PGBL possess anti-inflammatory properties, but its mechanism is poorly understood. Our research suggests that PGBL may inhibit TNF- $\alpha$ and IL-6 gene and protein

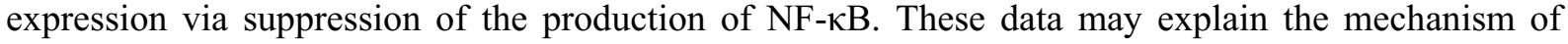
PGBL in anti-inflammatory activity. 


\section{Acknowledgments}

This study was supported by grants from the National Nature Science Foundation of China (31401201) and the National Nature Science Foundation of Jilin province (3D512K713429).

\section{References}

[1] M. Remichkova, P. Dimitrova, S. Philipov and N. Ivanovska, Toll-like receptor-mediated anti-inflammatory action of glaucine and oxoglaucine, Fitoterapia 80 (2009), 411-414.

[2] B. Beutler, Innate immunity: An overview, Molecular Immunology 40 (2004), 845-859.

[3] R. Medzhitov, Origin and physiological roles of inflammation, Nature 454 (2008), 428-435.

[4] S. Goerdt and C.E. Orfanos, Other functions, other genes: Alternative activation of antigen-presenting cells, Immunity 10 (1999), 137-142.

[5] C. Nicholas, S. Batra, M.A. Vargo, O.H. Voss, M.A. Gavrilin, M.D. Wewers, D.C. Guttridge, E. Crotewold and A.I. Doseff, Apigenin blocks lipopolysaccharide-induced lethality in vivo and proinflammatory cytokines expression by inactivating NF- $\mathrm{KB}$ through the suppression of p65 phosphorylation, The Journal of Immunology 179 (2007), 71217127.

[6] S.O. Enginler, A. Ateş, S.B. Diren, B.H. Sontaş, K. Sönmez, E. Karaçam, H. Ekici, D.G. Evkuran and A. Gürel, Meaurement of C-reactive protein and prostaglandin F2 $\alpha$ metabolite concentrations in differentiation of canine pyometra and cystic endometrial hyperplasia/mucometra, Reproduction in Domestic Animals 49 (2014), 641-647.

[7] H. Tannenbaum, P. Davis, A.S. Russell, M.H. Atkinson, W. Maksymowych, S.H. Huang, M. Bell, G.A. Hawker, A. Juby, S. Vanner and J. Sibley, An evidence-based approach to prescribing NSAIDs in musculoskeletal disease: A Canadian consensus, Canadian Medical Association Journal 155 (1996), 77-88.

[8] R. Fei, Y. Fei, S. Zheng, Y.G. Gao, H.X. Sun and X.L. Zeng, Purified polysaccharide from Ginkgo biloba leaves inhibits P-selectin-mediated leucocyte adhesion and inflammation, Acta Pharmacologica Sinica 29 (2008), 499-506.

[9] F.R. Greten and M. Karin, The IKK/NF- $\mathrm{kB}$ activation pathway-a target for prevention and treatment of cancer, Cancer Letters 206 (2004) 193-199.

[10] S. Dunzendorfer, H.K. Lee, K. Soldau and P.S. Tobias, TLR4 is the signaling but not the lipopolysaccharide uptake receptor, The Journal of Immunology 173 (2004), 1166-1170,

[11] Y. Ji, W.G. Qiang, Inhibition effects of valsartan on cell proliferation, expression inflammatory factors and reactive oxygen species production of macrophages, Journal of Shanghai Jiaotong University (Medical Science) 30 (2010), 292295.

[12] L. Boscá, M. Zeini, P.G. Través and S. Hortelano, Nitric oxide and cell viability in inflammatory cells: A role for NO in macrophage function and fate, Toxicology 208 (2005), 249-258.

[13] D. Sarkar, P. Saha, S. Gamre, S. Bhattacharjee, C. Hariharan, S. Ganguly, R. Sen, G. Mandal, S. Chattopadhyay, S. Mjumdar and M. Chatterjee, Anti-inflammatory effect of allylpyrocatechol in LPS-induced macrophages is mediated by suppression of iNOS and COX-2 via the NF-kB pathway, International Immunopharmacology 8 (2008), 1264-1271.

[14] A.V. Delgado, A.T. Mcmanus and J.P. Chambers, Production of tumor necrosis factor-alpha, interleukin 1-beta, interleukin 2, and interleukin 6 by rat leukocyte subpopulations after exposure to substance P, Neuropeptides 37 (2003), $355-361$.

[15] J.Y. Kim, S.J. Park, K.J. Yun, Y.W. Cho, H.J. Park and K.T. Lee, Isoliquiritigenin isolated from the roots of Glycyrrhiza uralensis inhibits LPS-induced iNOS and COX-2 expression via the attenuation of NF-kB in RAW264.7 macrophages, European Journal of Pharmacology 584 (2008), 175-184.

[16] M. Guha and N. Mackman, LPS induction of gene expression in human monocytes, Cell Signal 13 (2001), 85-94.

[17] G. Mancuso, A. Midiri, C. Beninati, G. Piraino, A. Valenti, G. Nicocia, D. Teti, J. Cook and G. Teti, Mitogen-activated protein kinases and NF- $\mathrm{kB}$ are involved in TNF-alpha responses to group B streptococci, The Journal of Immunology 169 (2002), 1401-1409.

[18] W.C. Sha, H.C. Liou, E.I. Tuomanen and D. Baltimore, Targeted disruption of the p50 subunit of NF- $\kappa$ B leads to multifocal defects in immune responses, Cell 80 (1995), 321-330.

[19] Q. Li and I.M. Verma, NF-אB regulation in the immune system, Nature Reviews Immunology 2 (2002), 725-734.

[20] S.I. Jang, H.J. Kim, Y.J. Kim, S.I. Jeong and Y.O. You, Tanshinone IIA inhibits LPS-induced NF- $\kappa B$ activation in RAW 264.7 cells: Possible involvement of the NIK-IKK, ERK1/2, p38 and JNK pathways, European Journal of Pharmacology 542 (2006), 1-7. 